African Journal of Biotechnology Vol. 8 (21), pp. 5867-5872, 2 November, 2009

Available online at http://www.academicjournals.org/AJB

DOI: $10.5897 / A J B 09.1068$

ISSN 1684-5315 @ 2009 Academic Journals

Full Length Research Paper

\title{
Enhanced production of subtilisin of Pyrococcus furiosus expressed in Escherichia coli using auto- inducing medium
}

\author{
Nadia Ikram ${ }^{1}$, Shumaila Naz ${ }^{1}$, M. Ibrahim Rajoka ${ }^{2}$, Saima Sadaf ${ }^{1,3}$ and M. Waheed Akhtar ${ }^{1 *}$ \\ ${ }^{1}$ School of Biological Sciences, University of the Punjab, Lahore-54590, Pakistan. \\ ${ }^{2}$ National Institute of Biotechnology and Genetic Engineering, Jhang Road, Faisalabad, Pakistan. \\ ${ }^{3}$ Institute of Biochemistry and Biotechnology, University of the Punjab, Lahore-54590, Pakistan.
}

Accepted 17 September, 2009

\begin{abstract}
A subtilisin gene identified in the reported genome sequence of Pyrococcus furiosus was amplified and inserted in $\mathrm{pET}-22 \mathrm{~b}(+)$ vector to produce the recombinant plasmid pET-SB. Escherichia coli BL-21 (DE3) CodonPlus was transformed with this plasmid and the enzyme was expressed up to $30 \%$ of the total cell protein on induction with IPTG. The expressed protein appeared at a position corresponding to $\sim 20 \mathrm{kDa}$ on SDS-PAGE as compared to theoretical molecular mass of $17.6 \mathrm{kDa}$. This aberrant electrophoresis mobility could be due to specific amino acid composition of the protein. Auto-induction with lactose also produced a similar level of expression but the total amount of the enzyme produced was 2.4 fold greater than that when produced with IPTG induction. This was due to a higher cell density obtainable in the auto-inducing medium. The enzyme expressed in the insoluble state could be partially refolded after denaturation with urea at high $\mathrm{pH}$. This study reports for the first time high-level expression of subtilisin of $\boldsymbol{P}$. furiosus in $E$. coli using an auto-inducing medium.
\end{abstract}

Key words: Subtilisin, Pyrococcus furiosus, auto-induction, enhanced production.

\section{INTRODUCTION}

Studies have continued to produce commercially important enzymes like proteases with better thermostability and other favorable properties for applications. Pyrococcus furiosus, an obligate anaerobic marine archaeon, has been the focus of significant biochemical and physiological studies because of its hyperthermophilic characteristics (Adams, 1993). Several proteins of $P$. furiosus, which function at temperatures greater than $90^{\circ} \mathrm{C}$ and enzymes displaying novel activities have been isolated and characterized (Leuschner and Antranikian, 1995). Many novel protease genes were identified by the whole genome sequencing project of $P$. furiousus. These proteases were reported to range in estimated molecular

${ }^{*}$ Corresponding author. E -mail: mwapu@brain.net.pk. Tel: +9242-9230970. Fax: +92-42-9230980. masses from 66 to $135 \mathrm{kDa}$, are highly stable at temperatures of $95^{\circ} \mathrm{C}$ and above and many are resistant to denaturation by sodium dodecyl sulfate (llse et al., 1990). Cell extracts from $P$. furiosus were found to contain five proteases, some of which were found resistant to denaturation by sodium dodecyl sulfate, $8 \mathrm{M}$ urea, $80 \mathrm{mM}$ dithiothreitol and 5\% $\beta$-mercaptoethanol (Halio et al., 1996; Hicks, 1998). A subtilisin-like cell envelope-associated protease was isolated from $P$. furiosus. It was thermostable up to a temperature of $115^{\circ} \mathrm{C}$ and had a half-life of more than 96 hours at $80^{\circ} \mathrm{C}$ and $4 \mathrm{~h}$ at $100^{\circ} \mathrm{C}$. It was found to have the highest homology to the subgroup of the subtilisin-like serine proteases (Eggen et al., 1990; Voorhorst et al., 1996).

We have previously reported cloning and expression of genes encoding carboxypeptidase (Ikram et al., 2008a) and a prolylendopeptidase (Ikram et al., 2008b) of $P$. furiosus in Escherichia coli. A subtilisin (SB) gene of $P$. 
furiosus was found at the locus_tag PF0688 in the reported genome sequence. This paper describes for the first time the expression of this gene in an auto-inducing medium and purification and refolding of the enzyme to an active state.

\section{MATERIALS AND METHODS}

\section{DNA, enzymes, kits and plasmids}

The genomic DNA of $P$. furiosus was obtained from the American Type Culture Collection (ATCC 43587). Taq DNA polymerase, T4 DNA ligase, restriction enzymes and InsT/Aclone ${ }^{T M}$ PCR product cloning kit were purchased from MBI Fermentas (USA) whereas QIAquick DNA gel extraction and QIAprep spin miniprep kits were acquired from QIAGEN, Inc. USA. pET-22b(+) expression plasmid was from Novagen, USA.

\section{Bacterial strains and culture media}

E. coli strains DH5a and BL21 (DE3) CodonPlus (Stratagene, USA) were used as cloning and expression hosts, respectively. E. coli were routinely grown in an orbital incubator shaker at $37^{\circ} \mathrm{C}$ and 150 rpm, unless stated otherwise. The cultivation media used in this study included LB, TB and M9NG and these were prepared as described earlier (Sambrook and Russell, 2001; Sadaf et al., 2007).

\section{Construction of pET-SB expression plasmid}

Based on the published sequence of SB gene (locus_tag PF0688), a pair of gene-specific forward (5'-ATAACATATGGCCCTAGG AGGATCTGC-3') and reverse (5'-GATGGATCCAAAAAGTTG TAGACC-3') primers was designed to amplify the gene fragment from the genomic DNA of $P$. furiosus. The forward and the reverse primers contained restriction sites for $\mathrm{Ndel}$ and $\mathrm{BamHI}$ (shown in bold), respectively, at their $5^{\prime}$ termini to facilitate the directional cloning. The PCR reaction was set up in $50 \mu \mathrm{l}$ reaction volume and the conditions used were: initial denaturation at $94^{\circ} \mathrm{C}$ for $3 \mathrm{~min}$ followed by 30 cycles of denaturation at $94^{\circ} \mathrm{C}$ for $45 \mathrm{~s}$, annealing at $58^{\circ} \mathrm{C}$ for $30 \mathrm{~s}$, extension at $72^{\circ} \mathrm{C}$ for $50 \mathrm{~s}$ and a final extension at $72^{\circ} \mathrm{C}$ for $20 \mathrm{~min}$ in an Applied Biosystem 2720 thermal cycler.

The amplicon was first cloned in $\mathrm{pTZ57R/T}$ vector by employing $\mathrm{dA} . \mathrm{dT}$ tailing technique and then subcloned in $\mathrm{pET}-22 \mathrm{~b}(+)$ at $\mathrm{Ndel} / \mathrm{BamHI}$ sites to generate the expression plasmid $\mathrm{pET}$-SB. The recombinant plasmid, thus obtained, was maintained in $E$. coli DH5a with ampicillin $(100 \mu \mathrm{g} / \mathrm{ml})$ as the selection antibiotic. The sequence and correct integration of insert were verified by restriction digestion and sequence analysis using Beckman Coulter $\mathrm{CEQ}^{\mathrm{TM}} 8000$ Genetic Analyzer.

\section{Expression analysis}

For the expression of cloned $S B$ gene, the plasmid pET-SB was transformed into $\mathrm{CaCl}_{2}$-competent $E$. coli BL21 (DE3) CodonPlus cells as described earlier (Ikram et al., 2008a, b). From the positive transformants, selected on LB-ampicillin plate, a single colony was inoculated in $10 \mathrm{ml}$ LB-ampicillin medium contained in a $100 \mathrm{ml}$ Erlenmeyer flask and incubated in a shaking incubator (IRmeco $\mathrm{GmbH}$, Germany) at $150 \mathrm{rpm}$ and $37^{\circ} \mathrm{C}$ overnight. Fresh $50 \mathrm{ml} \mathrm{LB}$ medium was inoculated with $1 \%$ overnight culture and incubated as described earlier. Protein expression was induced with either $1 \mathrm{mM}$ isopropyl- $\beta$-D-1-thiogalacto-pyranoside (IPTG) or $10 \mathrm{mM}$ lactose, when the culture $\mathrm{OD}_{600}$ reached $0.6-0.8$, unless stated otherwise. Following induction, cells were allowed to grow at $37^{\circ} \mathrm{C}$ shaking incubator with constant agitation. During cultivation, $1 \mathrm{ml}$ aliquots were collected after every one hour to monitor growth $\left(\mathrm{OD}_{600}\right)$ and analyze protein expression by $12 \%$ SDS-PAGE (Laemmli, 1970).

To analyze the expression of subtilisin-like protease in soluble and insoluble fractions, cells from an aliquot of the culture were harvested, washed with $0.05 \mathrm{M}$ Tris- $\mathrm{Cl}(\mathrm{pH} 7.5)$, resuspended in the same buffer to a final $O D_{600}$ of 10 , lysed by sonication in UP $400 S$ sonicator (dr. hielscher $\mathrm{GmbH}$, Germany) on ice by giving 10 bursts of one minute each with one minute interval between two successive pulses and then centrifuged at $4,500 \mathrm{rpm}$ for $20 \mathrm{~min}$. The soluble and insoluble fractions, thus obtained, were analyzed for the presence of the expressed enzyme by SDS-PAGE.

\section{Enzyme solubility and refolding}

Solubility of the recombinant enzyme, expressed as inclusion bodies, was checked in different solubilization buffers containing $0.05 \mathrm{M}$ Tris $-\mathrm{Cl}(\mathrm{pH} 8.0-11.0)$ and varying concentration of denaturing agent urea (2-8 M). Aliquots of the cell pellet containing equal amounts of the insoluble enzyme were resuspended in each of the solubilization buffer while stirring gently for $30 \mathrm{~min}$ at room temperature followed by centrifugation at $10,000 \mathrm{rpm}$ for $10 \mathrm{~min}$. Solubilization of the cell pellet contents was judged by measuring absorbance of the supernatant at $280 \mathrm{~nm}$ and turbidity at $450 \mathrm{~nm}$.

For refolding, the solubilized proteins were diluted with ice-cold refolding buffer [0.05 M Tris- $\mathrm{Cl}(\mathrm{pH} 8.0), 5 \mathrm{mM}$ EDTA, $0.05 \mathrm{M} \mathrm{L-}$ arginine] to a concentration of $\sim 200 \mu \mathrm{g}$ protein $/ \mathrm{ml}$. The mixture was incubated at $4^{\circ} \mathrm{C}$ for $12 \mathrm{~h}$ followed by dialysis against $0.05 \mathrm{M}$ Tris $-\mathrm{Cl}$ ( $\mathrm{pH}$ 8.0) overnight with three changes of the buffer during dialysis. Refolding efficiency was evaluated by using $500 \mu$ of each refolding sample for enzymatic assay.

\section{Enzyme assay}

$500 \mu \mathrm{l}$ of the appropriately diluted enzyme ( 250 $\mu \mathrm{g}$ protein) and $500 \mu \mathrm{l}$ of $0.5 \%$ solubilized azocasein (Sigma Aldrich Co., USA) were incubated at $70^{\circ} \mathrm{C}$ for $30 \mathrm{~min}$ in a shaking water bath. Following incubation, the reaction was stopped by adding $2 \mathrm{ml}$ of $10 \%$ trichloroacetic acid and the mixture was placed on ice for 10 $\min$. Precipitated proteins were separated by centrifugation at 6,500 rpm for $10 \mathrm{~min}$ and the amount of azo dye liberated in the supernatant was determined by measuring $\mathrm{OD}_{440}$ (Reichard et al., 1990). One unit of enzyme activity is defined as the amount of enzyme which releases $1 \mu \mathrm{g}$ amino acids equivalent to tyrosine per minute under the assay conditions.

\section{RESULTS AND DISCUSSION}

\section{Cloning and expression of SB gene}

The PCR amplified product of the SB gene, incorporating restriction sites for $\mathrm{Ndel}$ and $\mathrm{BamH1}^{\prime}$ at the $5^{\prime}$ and $3^{\prime}$ termini of the SB gene, respectively, was electrophoresed. The $\sim 500 \mathrm{bp}$ fragment was gel purified, T/A 


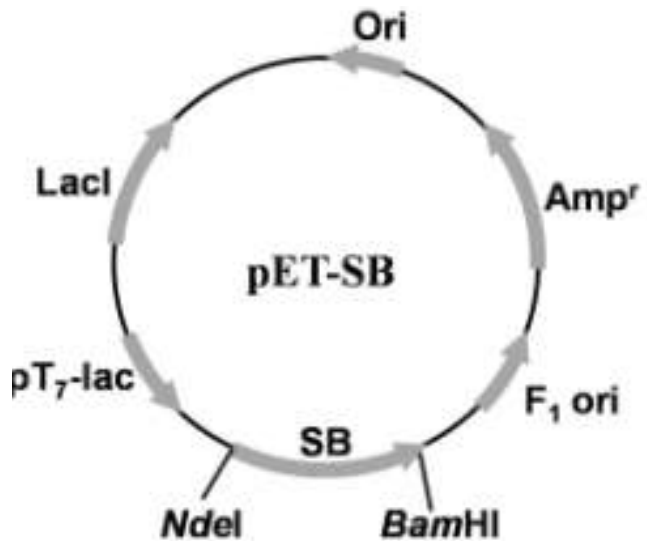

Figure 1. Recombinant plasmid pET-SB showing the position of 501 bp SB gene insert in the expression vector $\mathrm{pET}-22 \mathrm{~b}$.

cloned in $\mathrm{pTZ} 57 \mathrm{R} / \mathrm{T}$ and subcloned in $\mathrm{pET}-22 \mathrm{~b}(+)$ to generate $\mathrm{pET}-\mathrm{SB}$ expression plasmid (Figure 1). The expression plasmid was first maintained in E. coli $\mathrm{DH} 5 \alpha$ for vector propagation and then transformed into BL21 (DE3) CodonPlus for expression studies. Presence of the insert in the plasmid preparation from the positive transformants was confirmed by colony PCR (Figure 2). A prominent band of $\sim 0.5 \mathrm{~kb}$ as analyzed by agarose gel electrophoresis confirmed successful transformation. The correctness of the insert was also confirmed by nucleotide sequencing.

Proteins from the cells of the E. coli culture harboring pET-SB, when analyzed by SDS-PAGE, showed a prominent band at a position corresponding to $\sim 20 \mathrm{kDa}$ within initial $2 \mathrm{~h}$ of induction with $1 \mathrm{mM}$ IPTG. A band of similar size and intensity, however, was absent in the control and uninduced cells (Figure 3a). The expression levels increased gradually reaching a maximum of around $30 \%$ of the total $E$. coli cellular proteins, after 10 hours of induction. A study on the effect of IPTG concentration between $0.2-1.5 \mathrm{mM}$ showed that $0.5-1.0 \mathrm{mM}$ were the optimal levels for subtilisin expression (Figure $3 b$ ). However, it was observed that the size of expressed protein was slightly higher than the theoretical molecular mass of SB (17.6 kDa), as calculated through ExPASy Proteomics Server (www.expasy.ch). The expression analysis, repeated with multiple colonies, displayed similar results each time with a band of recombinant protein at a position corresponding to $\sim 20 \mathrm{kDa}$. It appears that SB probably exhibits an aberrant electrophoretic mobility on SDS-gel, which could be due to its specific amino acid composition. The contents of the negatively charged amino acids Glu and Asp in SB are around 12\%, which are relatively higher than usual contents. A recombinant a2/a8 hybrid interferon expressed in $E$. coli has also been

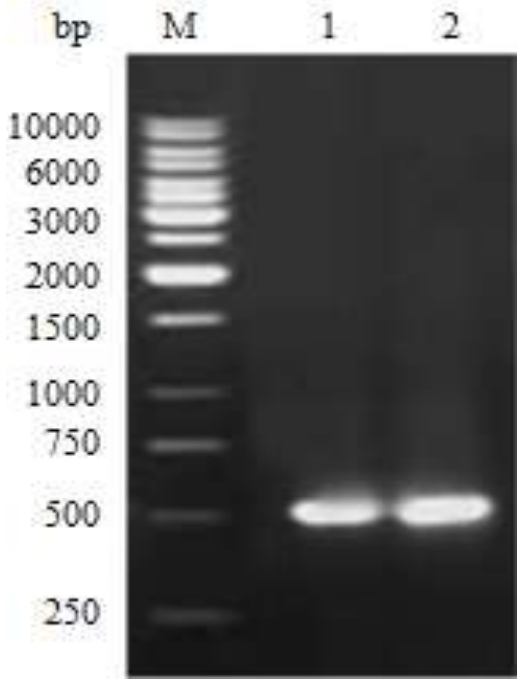

Figure 2. Agarose gel electrophoresis of the PCR product showing the presence of $S B$ insert in the recombinant plasmid isolated from two of the transformed cells. Lane $M$, size markers; Lanes 1 and 2, PCR product obtained from two different transformed cell colonies.

described to display aberrant mobility on SDS-gel due to high Glu/Asp content (Platis and Foster, 2003).

\section{Lactose induction}

The expression of recombinant SB in E. coli was studied by auto-induction with lactose, an inexpensive substitute for IPTG. Lactose at a concentration of $10 \mathrm{mM}$ in LB medium induced SB expression gradually reaching a maximum of $\sim 28 \%$ of the total cell proteins after $12 \mathrm{~h}$, as analyzed by SDS-PAGE electrophoresis (Figure 4a). A study on the effect of lactose concentration showed that the expression level increased with increase in lactose concentration up to $10 \mathrm{mM}$ (Figure 4b). Further increase in concentration seemed to have a negative effect on the expression level. $10 \mathrm{mM}$ lactose was, therefore, used as inducer in all subsequent experiments.

The expression of SB, when induced with lactose, was little delayed as compared to that in case of IPTG and also the level of maximum expression was a little lower. However, cell growth achieved in the LB medium following lactose induction was more than twice than observed with IPTG induction (Table 1). Accordingly, the final yield of SB in the lactose-medium was $281.4 \mathrm{mg} / \mathrm{L}$ as compared to $117 \mathrm{mg} / \mathrm{L}$ from the IPTG induced culture.

In order to enhance the production of SB, auto-induction 
(a)

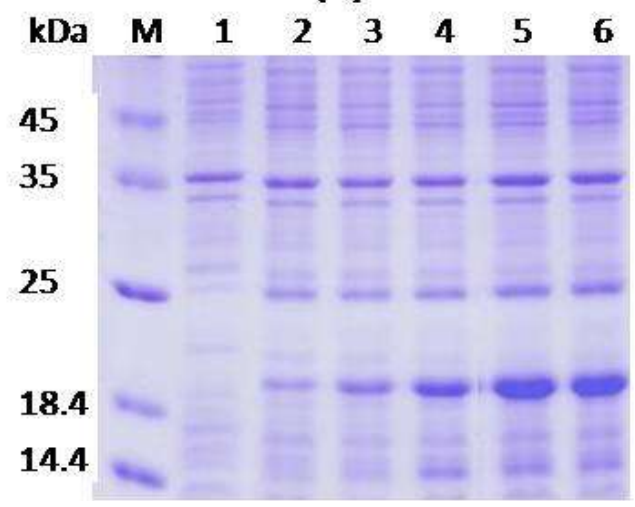

(b)

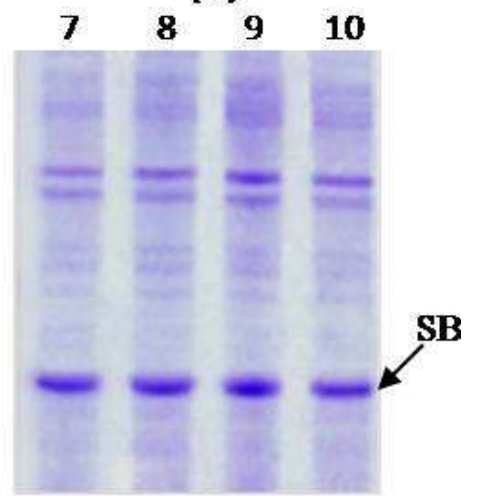

Figure 3. SDS-PAGE of total cell proteins of $E$. coli cells transformed with pET-SB and induced with $1 \mathrm{mM}$ IPTG for different time periods (a) and with different concentrations of IPTG (b). Lane M, protein markers; lanes $1-6$, cells induced with $1 \mathrm{mM}$ IPTG 1, 2, 4, 8, 10 and $12 \mathrm{~h}$, respectively; lanes 7 - 10, cells induced for $10 \mathrm{~h}$ with $0.2,0.5,1.0$ and $1.5 \mathrm{mM}$ IPTG, respectively.

(a)

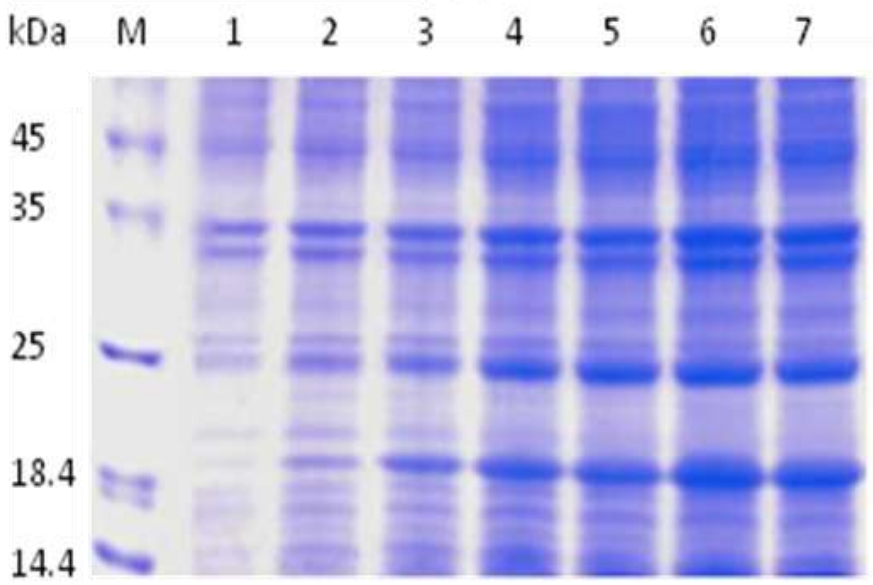

(b)

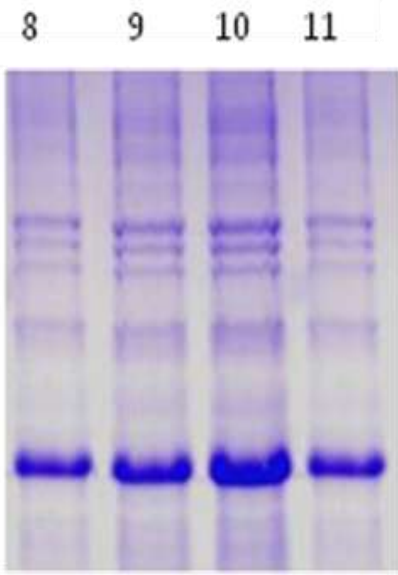

Figure 4. SDS-PAGE analysis of the total cell proteins of E. coli transformed with pET-SB and induced with $10 \mathrm{mM}$ lactose for different time periods (a) and with different concentrations of lactose for $12 \mathrm{~h}$ (b). Lane M, protein markers; lanes 1 - 7, cells induced with $1 \mathrm{mM}$ lactose for 2, 4, $6,8,10,12$ and $14 \mathrm{~h}$, respectively; lanes 8 - 11, cells induced for $12 \mathrm{~h}$ with $6,8,10$ and $12 \mathrm{mM}$ lactose, respectively.

with lactose was done in TB and M9NG media. Maximum $\mathrm{OD}_{600}$ attained in these media was 16.9 and 13.4, respectively, which was significantly higher than that observed in LB (Figure 5 and Table 2). Accordingly, the amount of SB obtained was 2 to 3-folds higher with 478 and $540 \mathrm{mg}$ SB per liter of cultivation media. Higher cell growth in M9NG and TB seems to parallel with the richness of nutrients. A little lower yield of SB from M9NG medium seems more attractive as it is comparatively cheaper cost.

\section{Refolding and purification}

An aliquot of subtilisin expressing $E$. coli cells was lysed by ultrasonication and both the supernatant and the insoluble pellet were analyzed by SDS-PAGE. Almost all the expressed SB was in the insoluble form (Figure 6, lane 2). A protein from an extreme thermophile when expressed in $E$. coli would be encountered with an environment, which is much different from that of the original organism especially with respect to temperature, 
Table 1. Comparison of SB production when induced with $1 \mathrm{mM}$ IPTG and $10 \mathrm{mM}$ lactose in LB medium.

\begin{tabular}{|c|c|c|c|c|c|c|c|c|}
\hline \multirow{2}{*}{$\begin{array}{c}\text { Time } \\
(\mathbf{h})\end{array}$} & \multicolumn{3}{|c|}{ IPTG } & \multicolumn{3}{c|}{ Lactose } \\
\cline { 2 - 8 } & $\mathbf{O D}_{\mathbf{6 0 0}}$ & TCP $^{*}(\mathbf{m g} / \mathbf{l})$ & Expression (\%) & SB (mg/l) & OD $_{600}$ & TCP* $\left.^{*} \mathbf{m g} / \mathbf{l}\right)$ & Expression (\%) & SB (mg/l) \\
\hline 4 & 1.2 & 180 & 6 & 10.8 & 1.6 & 245 & 5 & 12.3 \\
8 & 2.5 & 385 & 15 & 57.8 & 3.2 & 480 & 13 & 62.4 \\
12 & 2.6 & 390 & 30 & 117.0 & 6.7 & 1005 & 28 & 281.4 \\
\hline
\end{tabular}

${ }^{*}$ Total cell proteins.

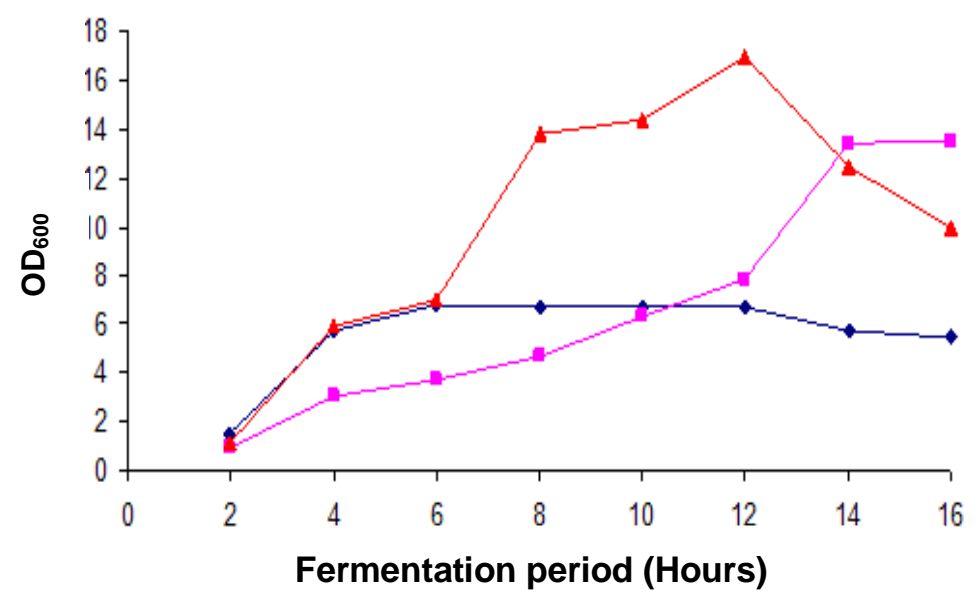

Figure 5. Growth profile of $E$. coli cells transformed with pET-SB and induced with $10 \mathrm{mM}$ lactose, when cultivated in LB $(\nabla)$, M9NG ( $)$ and TB ( $\boldsymbol{\Delta}$ ) media.

Table 2. Total cell proteins and the amounts of SB expressed in $E$. coli cells when cultivated in different media.

\begin{tabular}{|c|c|c|c|c|}
\hline Media & $\begin{array}{c}\text { Maximum } \\
\text { OD }_{600}\end{array}$ & $\begin{array}{c}\text { TCP } \\
(\mathbf{m g} / \mathbf{l})\end{array}$ & $\begin{array}{c}\text { SB } \\
\text { (\% of TCP) }\end{array}$ & $\begin{array}{c}\text { SB } \\
(\mathbf{m g} / \mathbf{l})\end{array}$ \\
\hline LB & 6.70 & 990 & 28 & 277 \\
M9NG & 13.4 & 1840 & 26 & 478 \\
TB & 16.9 & 2250 & 24 & 540 \\
\hline
\end{tabular}

thus preventing its correct folding.

The misfolded SB in the cell pellet was suspended in solution having increasing concentrations of urea. The proportion of solubilized protein (Figure 7a) and reduction in turbidity (Figure $7 \mathrm{~b}$ ) showed that, the solubility of inclusion bodies in Tris- $\mathrm{Cl}(\mathrm{pH} 11.0)$ containing $2 \mathrm{M}$ urea was higher than in Tris- $\mathrm{Cl}$ solution $(\mathrm{pH} 8.0)$ and $8 \mathrm{M}$ urea. The solubilized protein solution $(\sim 2 \mathrm{mg} / \mathrm{ml})$ was diluted ten-fold with the dilution buffer, incubated overnight at $4^{\circ} \mathrm{C}$ and dialyzed as described previously for refolding. Samples were collected during the entire expression, washing, solubilization, refolding and dialysis steps and

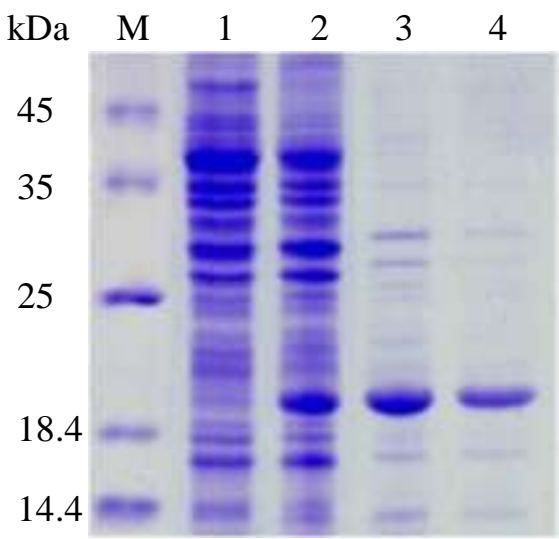

Figure 6. Refolding of subtilisin expressed in E. coli. Lane $\mathrm{M}$, protein markers; lane 1, supernatant of the cell lysate; lane 2, insoluble pellet from the cell lane 3 , insoluble pellet washed with buffer containing Triton X; lane 4 , refolded subtilisin.

subjected to SDS-PAGE to examine the purity of SB, which reached a level of around $92 \%$ without any 
Table 3. Summary of SB purification from $5.2 \mathrm{~g}$ wet weight of E. coli cells.

\begin{tabular}{|l|c|c|c|c|}
\hline \multicolumn{1}{|c|}{ Steps } & $\begin{array}{c}\text { TCP } \\
(\mathbf{m g})\end{array}$ & $\begin{array}{c}\text { SB } \\
(\mathbf{m g})\end{array}$ & $\begin{array}{c}\text { Recovery } \\
(\%)\end{array}$ & $\begin{array}{c}\text { Purity } \\
(\%)\end{array}$ \\
\hline Cell lysate & 650 & 169 & 100 & 26 \\
IBs & 280 & 162 & 96 & 58 \\
WIBs & 195 & 138 & 82 & 71 \\
Solubilization & 110 & 89 & 53 & 81 \\
Dialysis & 90 & 83 & 49 & 92 \\
\hline
\end{tabular}
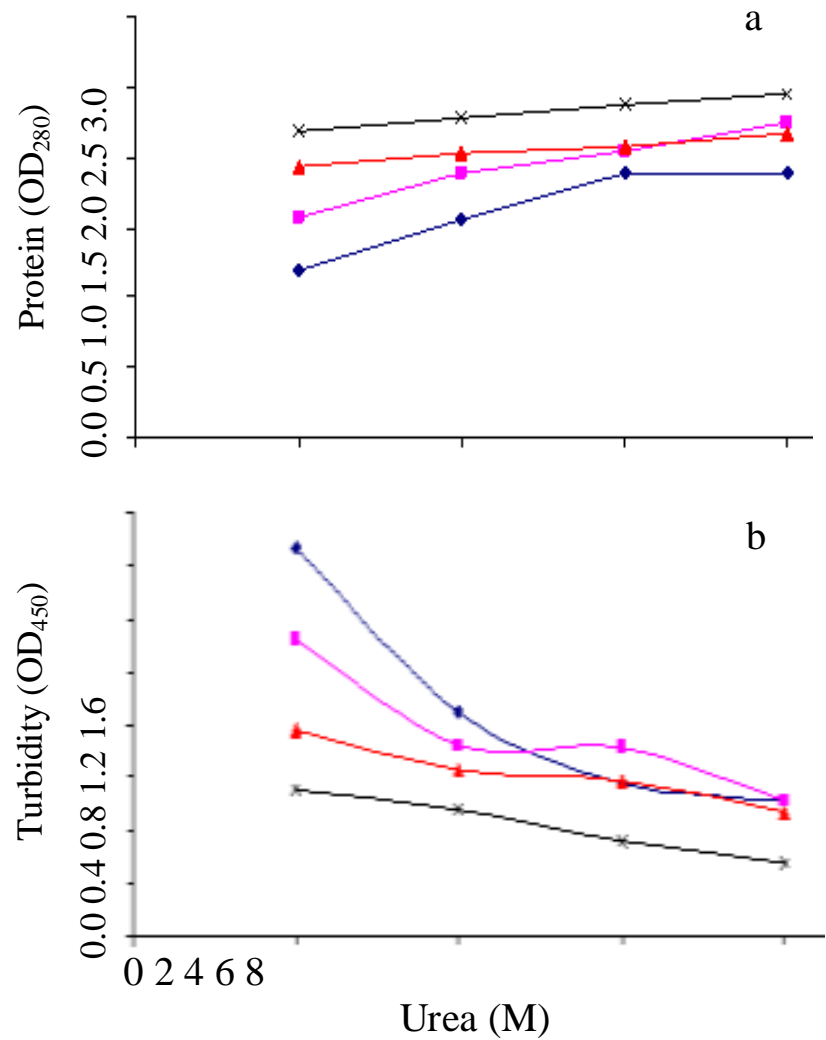

Figure 7. Effect of urea concentration on protein solublisation (a) and turbidity (b) in the lysate of $E$. coli cells expressing subtilisin, at $\mathrm{pH} 8.0(\bullet), 9.0(\boldsymbol{\square}), 10.0(\boldsymbol{\Delta})$ and $11.0(\mathrm{x})$.

chromatographic purification procedure (Figure 6 and Table 3).

Protease activity of the preparation thus obtained, as assayed using azocasein as substrate, was $114 \mathrm{U} / \mathrm{mg}$ protein. It appears that for expressing and obtaining proteins from extreme thermophiles like $P$. furiosus in the correctly-folded form, one would need to match the conditions the protein is likely to come across in the parent organism.

\section{ACKNOWLEDGEMENT}

The work reported in this paper was done under a research grant from Higher Education Commission, Islamabad, Pakistan.

\section{REFERENCES}

Adams MWW (1993). Enzymes and proteins from organisms that grow near and above $100^{\circ} \mathrm{C}$. Ann. Rev. Microbiol. 47: 627-658.

Eggen R, Geerling A, Watts J, Devos WM (1990). Characterization of pyrolysin, a hyperthermoactive serine protease from the archaebacterium Pyrococcus furiosus. FEMS. Microbiol. Lett. 71: 1720.

Halio SB, Blumentals II, Short SA, Merrill BM, Kelly RM (1996). Sequence, expression in Escherichia coli and analysis of the gene encoding a novel intracellular protease (Pfpl) from the hyperthermophilic archaeon Pyrococcus furiosus. J. Bacteriol. 178: 2605-2612.

Hicks PM (1998). Genetic, biochemical and biophysical characteristics of intracellular proteases from the hyperthermophilic archaeon Pyrococcus furiosus and the hyperthermophilic bacterium Thermotoga maritima. PhD dissertation, North Carolina State University.

Ikram N, Naz S, Akhtar MW (2008a). Expression of prolylendopeptidase of Pyrococcus furiosus in a partially folded form in E. coli. Pak. J. Biochem. Mol. Biol. 41: 153-157.

Ikram N, Naz S, Sadaf S, Akhtar MW (2008b). Overexpression of carboxypeptidase of extreme thermophile Pyrococcus furiosus in $E$. coli. Pak. J. Biochem. Mol. Biol. 41: 57-61.

Ilse I, Blumentals ASR, Kelly RM (1990) Characterization of sodium dodecyl sulfate-resistant proteolytic activity in the hyperthermophilic archaebacterium Pyrococcus furiosus. Appl. Environ. Microbiol. 56: 1992-1998.

Laemmli UK (1970). Cleavage of structural proteins during the assembly of the head of bacteriophage T4. Nature, 227: 680-685.

Leuschner C, Antranikian G (1995). Heat-stable enzymes from extremely thermophilic and hyperthermophilic microorganisms. World J. Microbiol. Biotechnol. 11: 95-114.

Platis D, Foster GR (2003). High yield expression, refolding and characterization of recombinant interferon $\alpha 2 / \alpha 8$ hybrids in Escherichia coli. Protein Express. Purif. 31: 220-230.

Reichard U, Buttner S, Eiffert H, Staib F, Ruchel R (1990). Purification and characterization of an extracellular serine proteinase from Aspergillus fumigatus and its detection in tissue. J. Med. Microbiol. 33: 243-51.

Sadaf S, Khan MA, Akhtar MW (2007). Production of bubaline somatotropin by auto-induction in E. coli. Biotechnol. Appl. Biochem. 47: 21-26.

Sambrook J, Russell DW (2001). Molecular Cloning: A Laboratory Manual, $3^{\text {rd }}$ Edition, Cold Spring Harbor Laboratory Press, Cold Spring Harbor, New York.

Voorhorst WGB, Eggen RIL, Geerling ACM, Platteeuw C, Siezen RJ, deVos WM (1996). Isolation and characterization of the hyperthermostable serine protease, pyrolysin and its gene from the hyperthermophilic archaeon Pyrococcus furiosus. J. Biol. Chem. 271: 20426-20431. 